\title{
Embryonic development of Girardia tigrina (Girard, 1850) (Platyhelminthes, Tricladida, Paludicola)
}

\author{
Vara, DC. ${ }^{\mathrm{a}}$, Leal-Zanchet, AM. ${ }^{\mathrm{a} *}$ and Lizardo-Daudt, HM. ${ }^{\mathrm{a}, \mathrm{b}}$ \\ ${ }^{1}$ Programa de Pós-Graduação em Biologia, Diversidade e Manejo de Vida Silvestre, Instituto de Pesquisas de Planárias, \\ Universidade do Vale do Rio dos Sinos - UNISINOS, \\ Av. UNISINOS, 950, CEP 93022-000, São Leopoldo, RS, Brazil

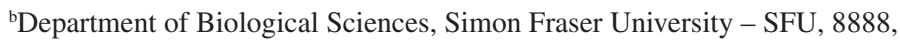 \\ University Drive, Burnaby, BC, V5A 1S6, Canada \\ *e-mail: zanchet@unisinos.br
}

Received April 4, 2007 - Accepted June 19, 2007 - Distributed November 30, 2008

(With 19 figures)

\begin{abstract}
The embryonic development of freshwater triclads is mainly known from studies of species of Dendrocoelum, Planaria, Polycelis, and, more recently, Schmidtea. The present study characterizes the development of Girardia tigrina (Girard, 1850) by means of optical microcopy using glycol methacrylate semi-thin sections. 94 cocoons were collected in the period from laying to hatching, with intervals of up to twenty-four hours. The sequence of morphological changes occurring in the embryo permitted the identification of nine embryonic stages. At the time of cocoon laying, numerous embryos were dispersed among many yolk cells, with a rigid capsule covering the entire cocoon. In the first stage (approx. up to 6 hours after cocoon laying), yolk cells and embryonic cells showed random distribution. Stage II (between 12 and 24 hours after cocoon laying) is characterized by aggregates of blastomeres, which later aggregate forming an enteroblastula. Approximately 2 days after cocoon laying (stage III), formation of the embryonic epidermis and embryonic digestive system took place, the latter degenerating during the subsequent stage. Stage V (until the fourth day) is characterized by the formation of the definitive epidermis. Between 4 and 6 days after laying, organogenesis of the definitive inner organs starts (stage VI). Approximately 14 days after laying (stage IX), formation of the nervous system is completed. At this stage, the embryo shows similar characteristics to those of newly hatched juveniles. The hatching of Girardia tigrina occurs in the period between twelve to twenty-two days after cocoon laying.
\end{abstract}

Keywords: developmental stages, morphology, optical microscopy, Dugesiidae, freshwater planarians.

\section{Desenvolvimento embrionário de Girardia tigrina (Girard, 1850) (Platyhelminthes, Tricladida, Paludicola)}

\begin{abstract}
Resumo
O desenvolvimento embrionário dos tricladidos é conhecido, fundamentalmente, por estudos realizados em espécies de Dendrocoelum, Planaria, Polycelis e, mais recentemente, Schmidtea. O presente estudo descreve o desenvolvimento embrionário de Girardia tigrina (Girard, 1850), a partir de análises realizadas em cortes histológicos seriados e semifinos de glicol-metacrilato, ao microscópio óptico. Noventa e quatro casulos foram coletados no período entre a postura e a eclosão, em intervalos de até vinte e quatro horas. A seqüência das modificações morfológicas no embrião permitiu a identificação de nove estágios embrionários. Na postura dos casulos, envoltos por uma cápsula rígida, observam-se numerosos embriões dispersos entre grande quantidade de células vitelinas. No estágio I (aproximadamente até 6 horas após a postura), as células vitelinas e as embrionárias mostram uma distribuição aleatória. O estágio II (entre 12 e 24 horas após a postura) caracteriza-se pela formação de agrupamentos de blastômeros, os quais posteriormente formam uma enteroblástula. Aproximadamente dois dias após a postura (estágio III), ocorre a formação da epiderme e do sistema digestivo embrionário, sendo que este último degenera no estágio seguinte. O estágio $\mathrm{V}$ (até o quarto dia após a postura) caracteriza-se pela formação da epiderme definitiva. Entre o quarto e o sexto dia posteriores à postura, começa a organogênese dos órgãos internos definitivos (estágio VI). Aproximadamente catorze dias após a postura (estágio IX), completa-se a formação do sistema nervoso. Neste estágio, o embrião já apresenta características similares aos espécimes juvenis. A eclosão de Girardia tigrina ocorre entre doze e vinte e dois dias após a postura dos casulos.
\end{abstract}

Palavras-chave: estágios do desenvolvimento, morfologia, microscopia óptica, Dugesiidae, planárias de água doce. 


\section{Introduction}

Freshwater planarians inhabit streams, spring ponds and lakes in temperate and tropical regions. They are predators, feeding on a wide range of invertebrates such as crustaceans, annelids, and snails (Reynoldson and Young, 2000). Planarians show complex female gonads, i.e., ovaries containing alecithal eggs and vitellaria showing cells rich in yolk. After fertilization, many alecithal eggs and vitelline cells are enveloped by a hard egg capsule called cocoon (Hyman, 1951; Benazzi and Gremigni, 1982). Following fertilization, cocoons are layed, the juveniles hatching after a variable period of time, depending on temperature and species.

Freshwater planarians belong to the infraorder Paludicola (Platyhelminthes: Tricladida), which is divided into three families: Dugesiidae, Planariidae and Dendrocoelidae. They are easily cultured in the laboratory, and their phyletic position and capability for sexual and asexual reproduction, among other characteristics, have attracted the attention of researchers of developmental biology (Hyman, 1951; Benazzi and Gremigni, 1982; Newmark and Alvarado, 2002; Alvarado, 2003; Cardona et al., 2005; 2006). Morphological descriptive studies on the embryonic development of freshwater triclads have, until now, been mainly undertaken in organisms of the families Planariidae (Planaria and Polycelis) and Dendrocoelidae (Dendrocoelum). Studies on the embryonic development of the family Dugesiidae, comprising ten genera (Sluys, 2001), were mainly pursued with Schmidtea (Benazzi and Gremigni, 1982; Cardona et al., 2006). Except for a note given regarding the formation of the pharynx of Girardia tigrina (Girard, 1850) (Curtis, 1902), the embryonic development in the genus Girardia is unknown.

Girardia tigrina is a cosmopolitan species, but shows differences in its reproductive behavior among different localities, as well as between the temperate and tropical climates. In North America and Europe, for example, populations of this species alternate sexual and asexual cycles throughout the year, or remain permanently asexual (Curtis, 1902), whereas in Southern countries the species undergoes sexual reproduction all year long (Marcus, 1946). In the present study, we analyzed the development of $G$. tigrina, by means of optical microscopy, with the aim of describing the sequence of the main morphological changes occurring between cocoon laying and hatching.

\section{Material and Methods}

Cocoons were obtained from a laboratory culture of Girardia tigrina (Girard, 1850) (Instituto de Pesquisas de Planárias, UNISINOS, São Leopoldo, RS, Brazil). 80 adult specimens were kept at $20 \pm 1{ }^{\circ} \mathrm{C}$ in Petri dishes with well-water. Cocoons were fixed immediately after laying and at 2, 4, 6, 12, 18 and 24 hours after laying during the first day. After that, cocoons were collected and fixed on a daily basis. 94 cocoons, which had the laying time noted and registered, were collected. Approximately 10 cocoons from each stage were analyzed.

Fixation and histological processing of the cocoons were performed according to Vara et al. (2001). Cocoons were fixed with SUSA, Bouin, or a variation of Karnovsky's fixative solution containing paraformaldehyde and glutaraldehyde, and embedded in glycol methacrylate. Serial sections (2-3 $\mu \mathrm{m}$ thick) were stained with toluidine blue (Spurlock et al., 1966), methylene blue/ basic fuchsin (Bennett et al., 1976), or hematoxiline/ eosine (Böck, 1984).

A classification of the stages of embryonic development was determined, based on the morphological characteristics of the yolk cells, epidermis, and the development of the digestive and nervous systems. These morphological criteria and the nomenclature used were based on Le Moigne (1963) and Benazzi and Gremigni (1982).

\section{Results}

Freshly deposited cocoons were light brown, becoming dark brown within few hours. Most cocoons presented an ovoid form, with the largest axis measuring 0.7 to $1.3 \mathrm{~mm}$. Four to 16 embryos per cocoon were observed, all passing synchronously through a number of embryonic stages. Nine stages were characterized:

Stage I (between 0 and 12 hours after laying) Immediately after cocoon laying, 4 to 16 egg cells, within a large number of yolk cells, are observed. Egg cells (see Figures 1-2) exhibit round or ovoid nucleus and one to two prominent nucleoli. Two types of yolk cells are distinguishable, both larger than egg cells. Type I vitelline cells, the more numerous; show a small round heterochromatin-rich nucleus $(6-9 \mu \mathrm{m})$ with one nucleolus. Type II vitelline cells have a usually larger $(7-11 \mu \mathrm{m})$ and spherical or ovoid euchromatin-rich nucleus with 1 to 2 nucleoli, showing its heterochomatin mainly peripherally displaced. Embryogenesis starts at the end of this stage.

Stage II (between 12 and 24 hours after laying) Mitotic division of egg cells results in a varied number of blastomeres, some of them forming aggregates, dispersed among vitelline cells. Later, these aggregates form a spherical blastem with an eccentric small cavity (enteroblastula) (see Figure 3).

Stage III (approximately 2 days after laying) Initiated with formation of an embryonic epidermis (see Figures 4-5) constituted by flattened cells with an underlying fibrous tissue. Vitelline cells form a syncytium surrounding each embryo; although many vitelline cells are observed among the blastomeres and dispersed within the cocoon (see Figures 4-5). Later, at one of the poles, the embryo shows a tubular organ, the embryonic pharynx (as shown in Figures 6-7), which is lined with cuboidal epithelium, and coated with a fibrous tissue. Small round cells delimit the communication of the pharyngeal lumen with the interior of the embryo. Distally to the 

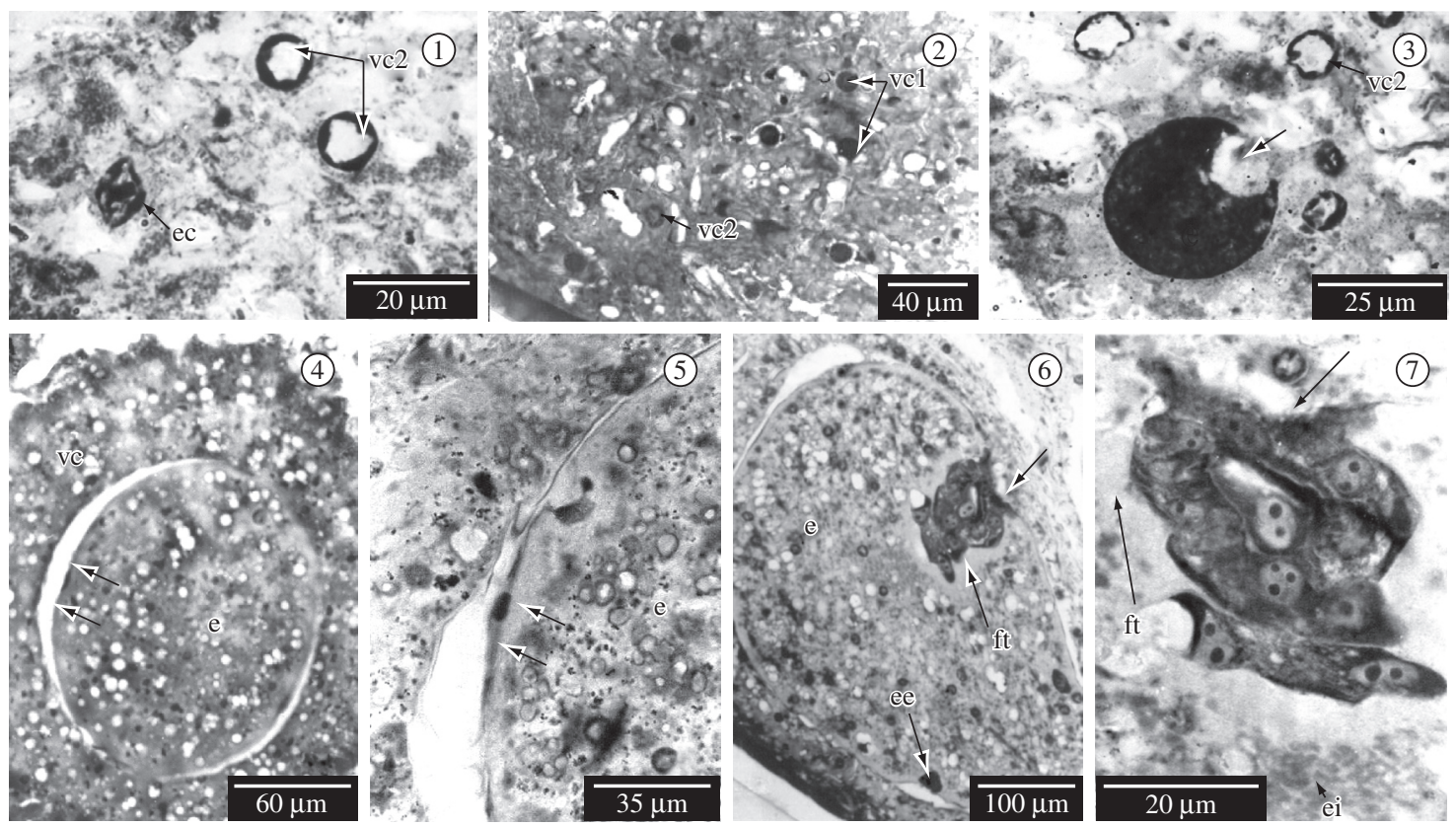

Figures 1-7. Semi-thin sections of cocoons of Girardia tigrina stained with methylene blue/ basic fuchsine (Figures $1,3,4)$ or toluidine blue (Figures 2, 5-7). Figures 1-2) Stage I, in an early phase, showing embryonic cells and the two types of yolk cells. Figure 3) Stage II, in an advanced phase, showing the blastomeres aggregating in a spherical blastema (enteroblastula) presenting an eccentric small cavity (arrow). and Figures 4-7) Stage III, in an early phase (Figures 4-5), presenting the formation of an embryonic epidermis (arrows). In an advanced phase (Figures 6-7), the embryo shows the embryonic pharynx (arrow) and intestine. e) embryo; ec) embryonic cells; ee) embryonic epidermis; ei) embryonic intestine; ft) fibrous tissue; vc) vitelline cells; vc1) vitelline cells of type I; and vc2) vitelline cells of type II.

embryonic pharynx, the fibrous tissue forms a sacculiform structure, which accumulates vitelline cells, similar to an embryonic intestine (see Figure 7).

Stage IV (approximately 3 days after laying) - The embryonic epidermis is comprised of a single layer of cubic to flattened cells (Figure 8). All the yolk cells, which were placed around the embryo in the previous stage, are absorbed into the embryo. The embryonic pharynx degenerates (see Figure 9), not being observed from this stage onward.

Stage V (until the fourth day after laying) Undifferentiated cells accumulate under the embryonic epidermis, which becomes thicker and multilayered due to proliferation of the undifferentiated cells, thereby giving origin to the definitive epidermis. A group of epidermic cells delaminates (as shown in Figure 10), and more internally, the movement of some epidermal cells forms a split (see Figure 11). The delamination determines the site of the definitive pharynx, whereas the split corresponds to the site of the definitive intestine.

Stage VI (between 4 and 6 days after laying) - The organogenesis of most of the definitive organs starts at this stage. In the ventral region, the embryo presents the beginning of the formation of the definitive pharynx (see Figure 12). This organ has an internal cavity lined by an epithelium in an early stage of formation with an underlying connective tissue, besides muscle fibres disposed in a radial manner. A saccular organ with a blind end, containing a small amount of yolk, represents the beginning of the definitive intestine (as shown in Figure 12). The embryos are spherical, and internally present a number of vitelline cells in different stages of degeneration.

Stage VII (between 6 and 8 days after laying) - The pharynx, located approximately in the third quarter of the body, shows a lining epithelium with an underlying connective tissue, internal and external muscle layers and radial muscles (see Figure 13). Muscle fibres disposed in various directions are observed within the embryonic mesenchyme. The vitelline cells become an amorphous mass. The embryos have not yet exhibited their definitive form, but are more elongated in the future antero-posterior axis than in former stages.

Stage VIII (at an average of 8 days after laying) Great alterations take place on preparing the embryo for hatching. The mesenchyme shows incompletely formed dorso-ventral muscle fibers (see Figure 14). The ventral epidermis presents cilia, and the dorsal epidermis, thicker than the ventral one, has rhabdites as observed in juveniles. The pharynx contains necks of the pharyngeal glands between external and internal epithelia (as shown in Figure 15). The intestine presents one main branch with small lateral diverticula. The intestinal lumen is filled with degenerated vitelline cells forming an amorphous mass. The nervous system appears, being repre- 


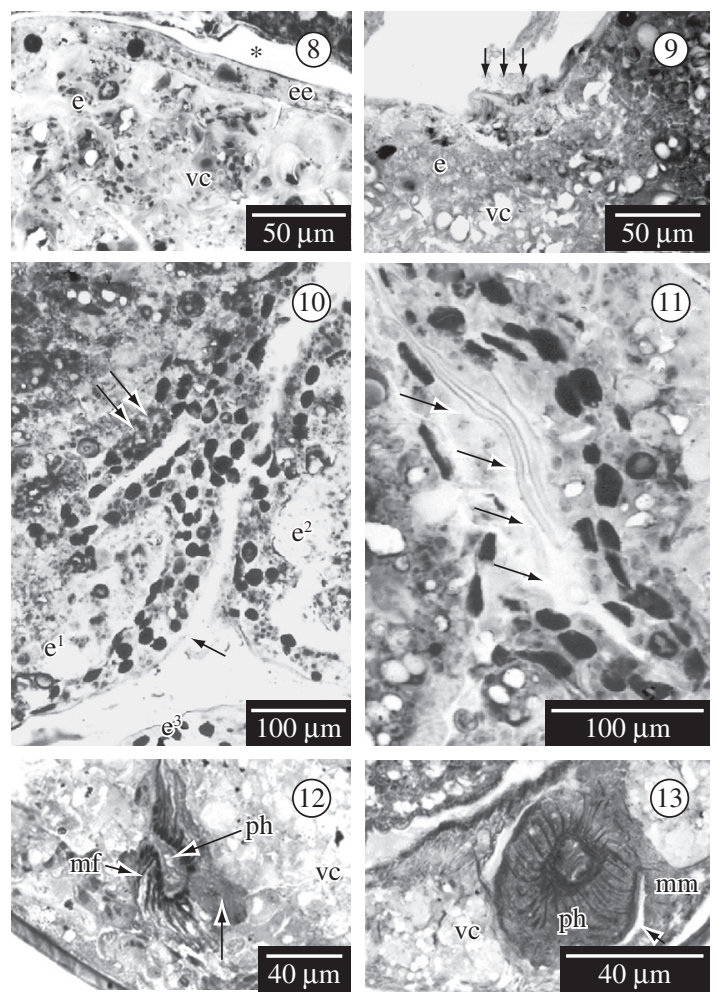

Figures 8-13. Semi-thin sections of cocoons of Girardia tigrina stained with toluidine blue (Figures 8, 10-13) or hematoxyline/ eosine (Figure 9). Figures 8-9) Stage IV, showing the embryonic epidermis (Figure 8) and the degeneration of the embryonic pharynx (arrows, Figure 9). The asterisk indicates the space between embryos without yolk. Figures 10-11) Stage V, presenting a thick embryonic epidermis (Figure 10, arrow), and the delamination of some epidermal cells (double arrow) giving rise to a split (Figure 11, arrows). Figure 12) Stage VI, showing the beginning of the formation of the definitive pharynx and the definitive intestine (arrow) and Figure 13) Stage VII, showing the mesenchyme and the definitive pharynx (arrow). The pharynx shows the internal and external muscle layers and the radial muscles. e) embryo; $\mathrm{e}^{1}-\mathrm{e}^{3}$ ) embryos; ee: embryonic epidermis; mf) muscle fibres; mm) mesenchymatic muscles; ph) pharynx; and vc) vitelline cells.

sented by the cerebral ganglia, whereas the formation of the eye pigment cup has started (see Figure 16). The embryo has assumed a dorso-ventrally flattened shape.

Stage IX (at an average of 14 days after laying) - The intestine shows a long anterior branch and two shorter posterior ones. There is no yolk in the ample intestinal lumen. Fixed mesenchymal cells and free undifferentiated cells are numerous especially between the intestinal diverticula. The longitudinal nerve cords and the cerebral ganglia present their definitive form, the latter being separated by the anterior intestinal branch. The eyes are completely formed (as shown in Figure 17). The embryos (see Figure 18), already 0.8-4.5 mm long, show all the juvenile characteristics.
Juveniles hatch between 12 and 16 days after cocoon laying, although in some cases a period of up to 22 days before hatching has been registered. The newly hatched juveniles are between 2 and $5 \mathrm{~mm}$ long.

The main morphological changes are summarized in Figure 19.

\section{Discussion}

The embryonic development of triclads denotes a very variable duration, being slower at low temperatures. Cocoon hatching in Polycelis nigra (Müller, 1773) varies between 21 and 40 days after cocoon deposition with a maximal frequency of hatching between 24 and 28 days at $18{ }^{\circ} \mathrm{C}$ (Le Moigne, 1963). In the present study, hatching of $G$. tigrina occurred between 12 and 22 days after cocoon laying, with maximal hatching frequency occurring between 12 and 16 days after cocoon deposition (at $20 \pm 1{ }^{\circ} \mathrm{C}$ ). A population of the same species in a region of tropical climate shows cocoon hatching occurring between 5 and 29 days (Preza, 1995).

The triclads, and some representatives of other neophoran orders, reveal a highly modified cleavage compared to the spiral quartet or duet form occurring in most arcoophorans (Thomas, 1986). This is a consequence of the large amount of external yolk inside the cocoon that interferes with embryonic development. The egg divides, blastomeres dispersing without becoming attached to each other ("Blastomeren-Anarchie") (Baguña and Boyer, 1990; Alvarado, 2003; Cardona et al., 2005; 2006). Segmentation is so irregular that the fate of blastomeres, the precise origin of cell lines and organs, and a gastrula stage cannot be identified (Benazzi and Gremigni, 1982; Alvarado, 2003). In G. tigrina we observed this irregular segmentation followed by aggregation into a solid blastema, as described for some other triclads (Thomas, 1986).

In triclads, asynchronous development in eggs of the same cocoon can occur (Benazzi and Gremigni, 1982), but in G. tigrina we always observed the embryos of a cocoon in the same stage of development.

In the present study, morphological analysis of the development of $G$. tigrina indicates the occurrence of two types of yolk-cells, similar to the statements of other authors (Le Moigne, 1963; Benazzi and Gremigni, 1982; Marinelli and Vagnetti, 1973; Alvarado, 2003; Cardona et al., 2005; 2006). After Cardona et al. (2006), the second type of yolk cells of Schmidtea polychroa (Schmidt, 1861), the so-called fusiform yolk cells, differentiates from spherical yolk cells. They become apparent within the first day after laying, and are the most numerous yolk cells within the egg capsule during the second and third day after laying (Cardona et al., 2006). In our material of $G$. tigrina, observed by means of optical microscopy, the most numerous yolk cells (named type I herein), presenting a heterochromatin-rich nucleus with a well-developed nucleolus, may correspond to the type I yolk cells described by Le Moigne (1963) and 

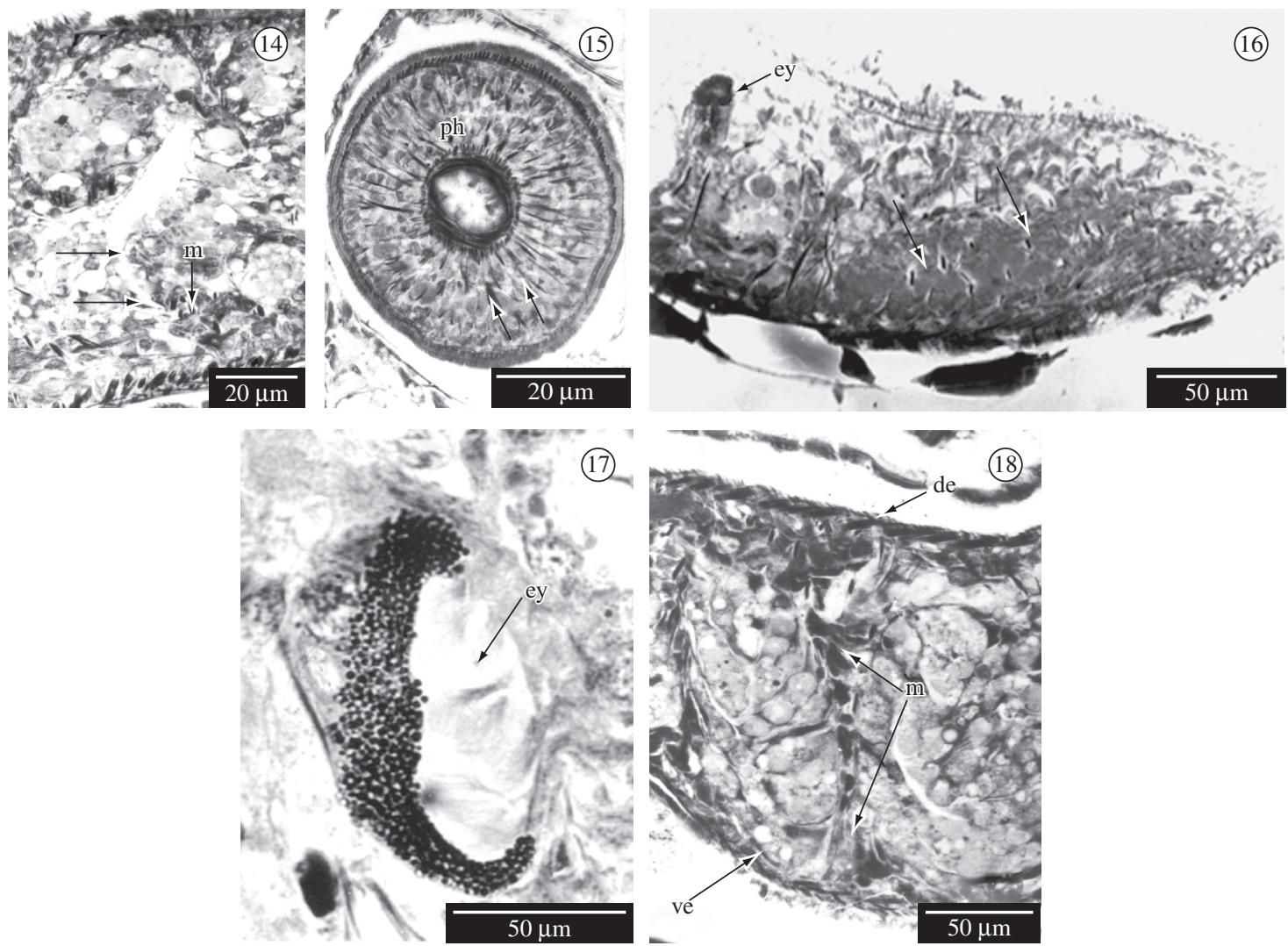

Figures 14-18. Semi-thin sections of cocoons of Girardia tigrina stained with toluidine blue. Figures 14-16) Stage VIII, having the mesenchyme with incompletely formed dorso-ventral muscle fibers (arrows) (Figure 14). Figure 15 shows the definitive pharynx containing necks of the pharyngeal glands (arrows); Figure 16 shows the cerebral ganglium (arrows) and the beginning of the eye pigment cup formation. and Figures 17-18) At stage IX, the embryo has similar characteristics to those of newly hatched juveniles. Figure 17 shows a completely formed eye; Figure 18 shows a detail of the posterior region of the body. de) dorsal epidermis; ey) eye; m) mesenchyme; mf) muscle fibres; ph) pharynx; and ve) ventral epidermis.

Marinelli and Vagnetti (1973) and to the round yolk-laden cells described by Cardona et al. (2006). According to Le Moigne (1963), the more numerous type of yolkcells of P. nigra (type I) is destined to be engulfed and digested by the embryo and the second type of yolk cell will form the yolk syncytium where blastomeric division takes place.

The morphological changes documented on the cocoons of triclads came mainly from detailed studies in P. nigra (Le Moigne, 1963) and, more recently, in S. polychroa (Cardona et al., 2005; 2006). For these species, seven and eight stages of development, respectively, were described (Le Moigne, 1963; Cardona et al., 2005). Girardia tigrina showed a similar sequence of developmental events with certain differences, leading us to characterize nine stages of development. The similarities between the three species are: multiplication of blastomeres, dissociating and spreading in the yolk syncicium (stage I), formation of an embryonic epidermis and embryonic digestive system (stages II of P. nigra and S. polychroa and III of G. tigrina), formation of a embryonic gut cavity which contains the yolk cells en- gulfed by the embryonic pharynx (stages III of P. nigra and S. polychroa and IV of G. tigrina), the development of the definitive organs (stages $\mathrm{V}$ of $P$. nigra and VI in S. polychroa and G. tigrina), the elongation of the embryo in the antero-posterior axis (stages $\mathrm{V}$ of $P$. nigra and VI in S. polychroa and VII in G. tigrina), and the formation of eyes, besides the complete differentiation of the digestive system and epidermis (stage VI/VII of $S$. polychroa, stages VI/VII of P. nigra, and VIII/IX of G. tigrina).

Among the differences between the development of G. tigrina and the two species commented above, it must be pointed out the formation of a blastema (enteroblastula) in stage II. Between the better studied freshwater triclads, a regular blastula-shaped structure was described only by Mattiesen (1904) and Koscielski (1966) for Dendrocoelum lacteum Oersted, 1844. Both authors observed blastomeres regularly arranged on the periphery of a spherical syncytium. Although a relatively similar structure could also be observed in G. tigrina, our data shows an enteroblastula with an eccentric small cavity, unlike the regular blastula described for D. lacteum. 

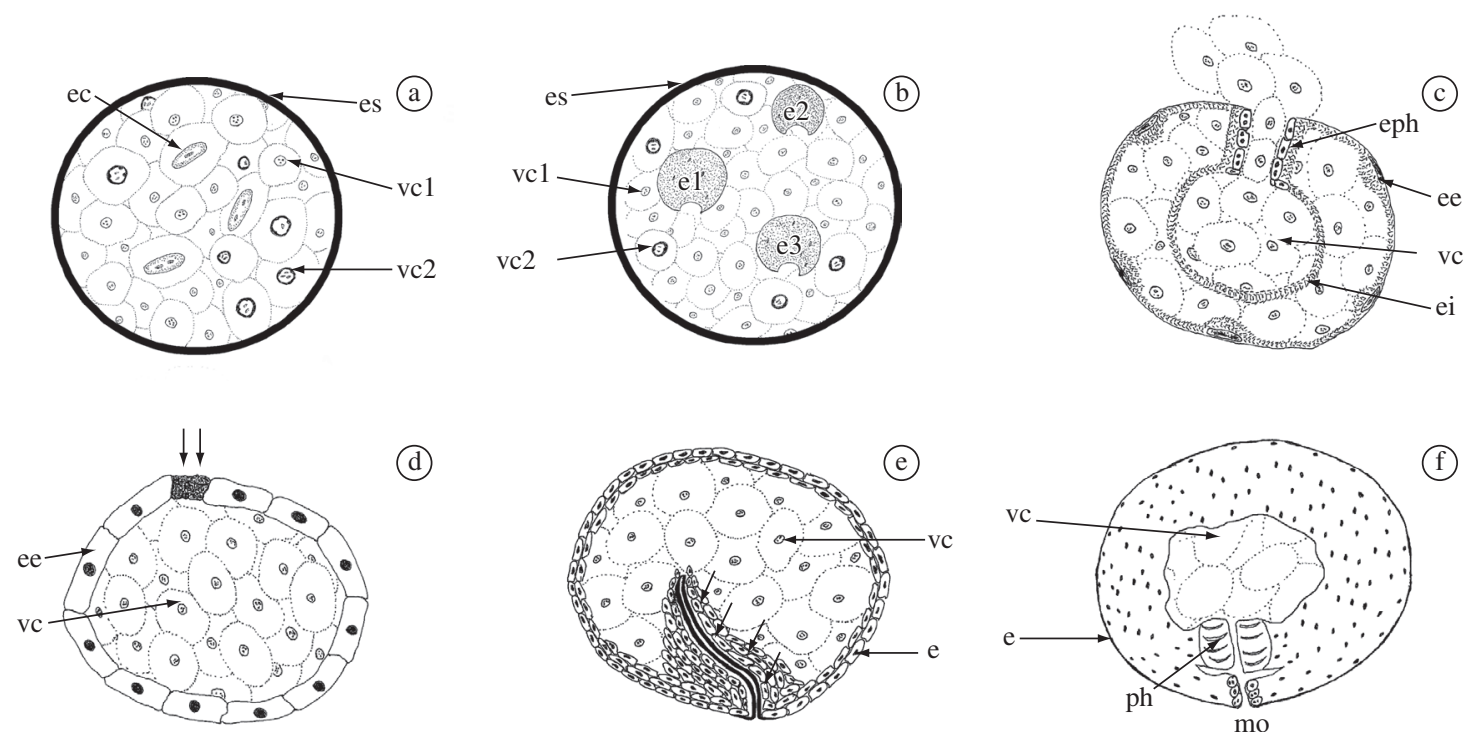

(d)
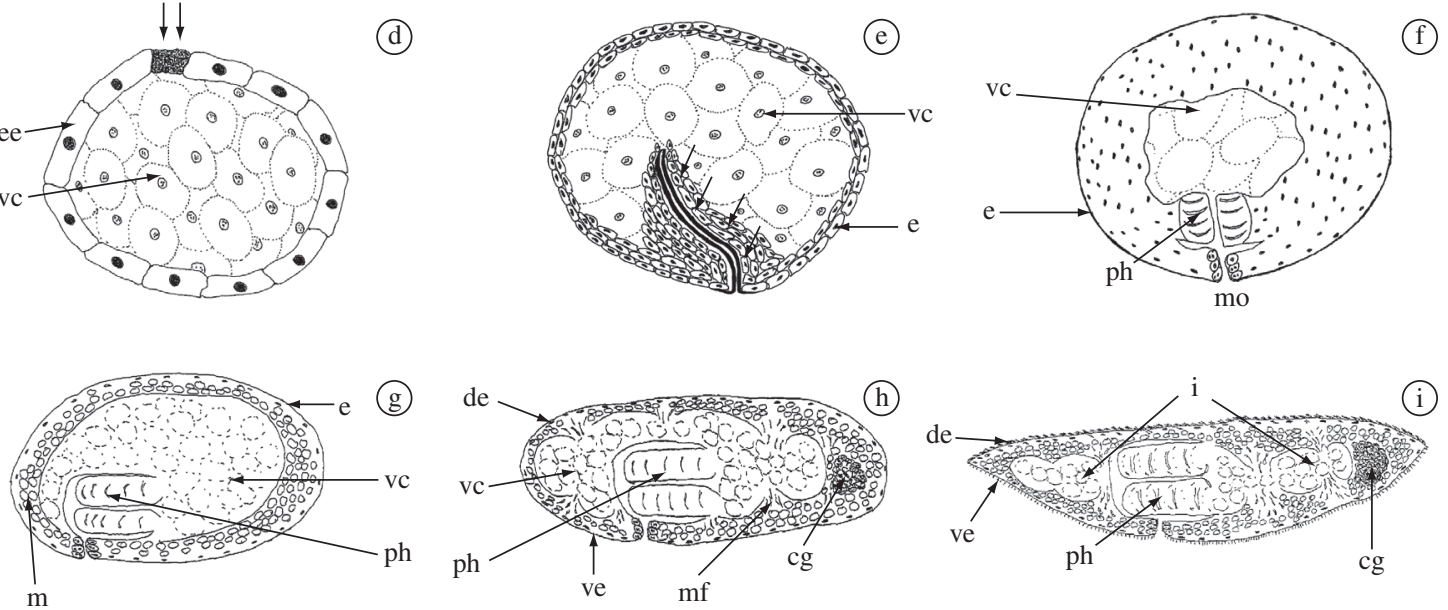

Figure 19. Schematical drawing showing the main characteristics of the embryonic developmental stages of Girardia tigrina between cocoon deposition and hatching. a-b) show an egg capsule; and c-i) show an embryo. a) Stage I: embryonic cells are dispersed between numerous yolk cells; b) Stage II: Embryonic cells aggregate forming a round blastema with an eccentric small cavity; c) Stage III: Formation of embryonic epidermis and pharynx; d) Stage IV: Degeneration of the embryonic pharynx (double arrow); e) Stage V: Formation of the definitive epidermis and delamination of a group of epidermic cells (arrows) determining the site of the definitive pharynx; f) Stage VI: Early organogenesis with formation of definitive pharynx and intestine; g) Stage VII: Formation of the definitive pharynx is completed and the embryo stretches; h) Stage VIII: Formation of the nervous system; and i) Stage IX: Late differentiation with the embryo showing similar characteristics to those of the juveniles. cg) cerebral ganglium; de) dorsal epidermis; e) definitive epidermis; e1-e3) embryos; ec) embryonic cells; ee) embryonic epidermis; ei) embryonic intestine; eph) embryonic pharynx; es) eggshell; i) definitive intestine; m) mesenchyme; mf) muscle fibers; mo) mouth; ph) definitive pharynx; vc) vitelline cells; vc1) vitelline cells of type I; vc2) vitelline cells of type II; and ve) ventral epidermis.

According to Koscielski (1966), the occurrence of a blastula stage in an organism showing the phenomenon of Blastomeren-Anarchie represents a phylogenetic remnant.

The formation of the nervous system in P. nigra, $S$. polychroa and G. tigrina occurs when the embryo becomes dorso-ventrally flattened. However, delineation of the cerebral ganglia and organization of the definitive pharynx and intestine occur at the same stage in P. nigra (stage V) and S. polychroa (stage VI) (Le Moigne, 1963, Cardona et al., 2005), whereas in G. tigrina, the interval observed between formation of the definitive pharynx and development of the nervous system allowed us to distinguish between stages VII and VIII. The formation of the pharynx starts earlier (stage VII) than the delineation of the nervous system (stage VIII) in G. tigrina.
An embryonic digestive system, consisting of mouth, pharynx and intestine, which is involved in swallowing and digestion of the yolk, was described for several triclad species (Curtis, 1902; Mattiesen, 1904; Fulinski, 1938; Le Moigne, 1963). For specimens of G. tigrina from the United States, the embryonic pharynx is still visible when formation of the definitive pharynx begins (Curtis, 1902). This is not observed in South-Brazilian specimens of $G$. tigrina. The embryonic pharynx was observed approximately two days after cocoon deposition (stage III), with formation of the definitive pharynx starting between four and six days after cocoon deposition (stage VI). Similar to our results, in D. lacteum and in $S$. polychroa, the embryonic pharynx disintegrates before formation of the definitive pharynx started (Iijima, 1884; Mattiesen, 1904; Cardona et al., 2005). 
Acknowledgements - To FAPERGS (Fundação de Amparo à Pesquisa do Rio Grande do Sul) for financial support. To the anonymous referees, for their helpful comments and suggestions. To the technicians Welcy H. Santos, for maintaining the animals and cocoon collecting, Letícia A. Guterres and Jaqueline C. Rodrigues, for helping with histological techniques, and Vanessa A. Baptista and Teresinha H. Oliveira, for photographical work. To Rodrigo Perrone and Fabiano Gil, for their help with the preparation of the final version of the figures.

\section{References}

ALVARADO, AS., 2003. The freshwater planarian Schmidtea mediterranea: embryogenesis, stem cells and regeneration. Current Opinion in Genet. \& Dev., vol. 13, no.4, p. 438-444.

BAGUÑA, J. and BOYER, BC., 1990. Descriptive and Experimental Embryology of the Turbellaria: Present Knowledge, Open Questions and Future Trends. Exp. Embr. Aquat. Plant. Anim., vol. 12, p. 95-128.

BENAZZI, M. and GREMIGNI, V., 1982. Developmental biology of Triclad Turbellarians. In FW. HARRISON and R. COWDEN (Eds.). Developmental Biology of Freshwater Invertebrates. New York: Alan R. Liss. p. 151-221.

BENNETT, HS., WYRICK, AD. and MACNEIL, JH., 1976. Science and art preparing tissues embedded in plastic for light microscopy, with special reference to glycol methacrylate, glass knives and simple stains. Stain Technol., vol. 51, no. 2, p. 71-97.

BÖCK, P., 1984. Der Semidünnschnitt. München: JF. Bergmann Verlag. 172 p.

CARDONA, A., HARTENSTEIN, V. and ROMERO, R., 2005. The embryonic development of the triclad Schmidtea polychoa. Dev. Genes Evol., vol. 215, no.3, p. 109-131.

-, 2006. Early embryogenesis of planaria: a criptic larva feeding on maternal resources. Dev. Genes Evol., vol. 216, no. 11 , p. $667-681$.

CURTIS, WC., 1902. The life history, the normal fission, and the reproductive organs of Planaria maculata. Proc. Bost. Soc. Nat. Hist., vol. 30, p. 515-583.

FULINSKI, B., 1938. Zur Embryonalpharynxfrage der Trikladiden. Zool. Pol., vol. 2, p. 185-207.

HYMAN, LH., 1951. The Invertebrates. New York: McGrawHill. $550 \mathrm{p}$.
IIJIMA, I., 1884. Untersuchungen über den Bau und die Entwicklungsgeschichte der Süsswasser-Dendrocoelen (Tricladiden). Zeitsch. wiss. Zool., vol. 40, p. 359-464.

KOSCIELSKI, B., 1966. Cytological and cytochemical investigations on the embrionic development of Dendrocoelum lacteum O.F. Müller. Zool. Pol., vol. 16, no. 1, p. 83-102.

LE MOIGNE, A., 1963. Étude du développment embryonnaire de Polycelis nigra (Turbellarié, Triclade). Bull. Soc. Zool. Fr., vol. 88 , p. 403-422.

MARCUS, E., 1946. Sôbre Turbellaria límnicos brasileiros. Bol. Fac. Fil., Ciênc. Let. Univ. S. Paulo, vol. 11, p. 5-254.

MARINELLI, M. and VAGNETTI, D., 1973. Electron microscopic investigations on the yolk cells in the cocoon of Dugesia lugubris. Boll. Zool., vol. 40, p. 367-369.

MATTIESEN, E., 1904. Ein Beitrag zur Embryologie der Süsswasserdendrocölen. Zeitsch. wiss. Zool., vol. 38, p. 275-365.

NEWMARK, PA. and ALVARADO, AS., 2002. Not your father's planarian: a classic model enters the era of functional genomics. Nature Rev. Genet., vol. 3, no. 3, p. 210-219.

PREZA, DLC., 1995. Girardia tigrina (Girard, 1850) (Turbellaria: Tricladida: Paludicola): aspectos biológicos e seu emprego em testes de toxicidade. Bahia: Universidade Federal da Bahia. [Master's Dissertation]

REYNOLDSON, tb. and YOUNG, JO., 2000. A key of the freshwater triclads of Britain and Ireland with notes on their ecology. Ambleside: The Freshwater Biological Association. $71 \mathrm{p}$.

SLUYS, R., 2001. Towards a phylogenetic classification and characterization of dugesiid genera (Platyhelminthes, Tricladida, Dugesiidae): a morphological perspective. In LITTLEWOOD, DTJ. and BRAY, RA. (Eds.). Interrelationships of the Platyhelminthes. London: Taylor \& Francis. p. 57-73.

SPURLOCK, BO., SKINNER, MS. and KATTINE, AA., 1966. Simple rapid method for staining epoxi-embedded specimens for light microscopy with the polichromatic staining Paragon 1031. Amer. J. Clin. Pathol., vol. 46, no. 2, p. 252-258.

THOMAS, MB., 1986. Embryology of the Turbellaria and its phylogenetic significance, Hydrobiologia, vol. 132, no. 1, p. $105-115$.

VARA, DC., LEAL-ZANCHET, AM. and LIZARDO-DAUDT, HM., 2001. Histological processing techniques for the study of Dugesiidae development (Platyhelminthes, Tricladida, Paludicola). Braz. J. Biol = Rev. Bras. Biol.., vol. 61, no. 2, p. 341-345. 